\title{
Rancang Bangun Smart DC Current and Voltage Monitoring Dengan Thingspeak Pada Simulator PLN Laboratorium Teknik Tenaga Listrik UGM
}

Lukman Prihasworo, Dhanis Woro Fittrin, Unan Yusmaniar Oktiawati*, Hidayat Nur Isnianto dan Yulianus Wahyo Setyono

Departemen Teknik Elektro dan Informatika

Sekolah Vokasi, Universitas Gadjah Mada, Yogyakarta, 55281 Indonesia

*unan_yusmaniar@ugm.ac.id

\begin{abstract}
The progress of the digital world makes it easy for humans to access the needs needed by using a gadget or personal computer that they have, a system monitoring a system that used to use a conventional system that can be done by periodically checking manually, with technological advancements we can monitor a system regularly with just sitting in a room by opening an application that has been prepared before. In general, monitoring is used to display data in real time or periodically each time it aims to obtain data optimally and thoroughly to keep the system in a state normal in accordance with a predetermined nominal value and rating, and can anticipate unwanted things when the system is not operating normally, so special treatment can be determined to keep the system normal. The monitoring object to be carried out is to monitor the current and voltage of a power power supply that supplies electricity to a DC motor that is regulated using a variable rheostat or variable resistor in the PLN Simulator located at the Electrical Power Laboratory, Department of Electrical and Informatics Engineering, Vocational College, Universitas Gadjah Mada. The system is called Smart DC Current Voltage monitoring, where the word smart is reflecting technological progress. As known that human needs can be done by using gadgets with systems connected to the internet or online. Monitoring is made on the basis of an Arduino Mega 2560 microcontroller, which is used to process sensor data in the form of an ACS 71220 $B$ current sensor used as a current sensor with a current rating of 20 Amperes and a voltage sensor with a voltage rating of 220 Volts, the output of the sensor is digital data which will then if processed using the Arduino Mega 2560 which was made aimed at monitoring the flow and DC voltage at the work of a DC load, at the PLN simulator at the Electric Energy Engineering Laboratory. From the data obtained later it will be known how optimal the work of a tool to monitor the work of a DC motor. Measurement results using ACS 71220 B current sensor and voltage divider as a voltage sensor, the measurement results will be processed on the Ardino Mega 2560 microcontroller, with a predetermined formula and calibrated, so that data can be utilized, data from Arduino Mega 2560 will be transmitted to the WiFi module Nodemcu ESP 8266 via UART pin (RX PIN, TX PIN) between microcontrollers or commonly referred to as serial data communication systems, when they are connected and communicating in this case the WiFi Module Nodemcu ESP 8266 can receive data from Arduino Mega that can be monitored using the serial monitor provided in the Arduino IDE application, after being able to receive data and communicate with each other, the WiFi Module must be connected to an internet connection, which has been provided before. After that the data can be transmitted to a web server as Data collector with the platform chosen is thingspeak. The thing that needs to be done to access data on the Thingspeak platform is registering an account through the email address that we have, after being registered and having an account of our own we can input data through the Thingspeak field which is used to receive data from the WiFi Module Nodemcu ESP 8266. Measurement results can be monitored through the thingspeak application which must be installed on the gadget that is owned by the Thingspeak account login first.
\end{abstract}

Keywords - Smart DC current voltage monitoring, PLN Simulator, Current Sensor, Voltage Sensor, Mikrocontroller, Thingspeak.

Abstrak- Kemajuan dunia digital memudahkan manusia dalam mengakses kebutuhan yang diperlukan dengan menggunakan sebuah gadget atau personal komputer yang dimliki, sistem monitoring suatu sistem yang dulunya menggunakan sistem konvesional yang dapat dilakukan dengan manual checking secara berkala, dengan kemajuan teknologi kita dapat melakukan monitoring suatu sistem secara berkala dengan hanya duduk di suatu ruangan dengan membuka aplikasi yang telah disiapkan sebelumnya. Pada umumnya monitoring digunakan untuk menampilkan data secara real time atau secara berkala waktu tiap waktu hal ini bertujuan untuk mendapatkan data secara optimal dan teliti untuk menjaga sistem tetap dalam keadaan normal sesuai dengan nilai nominal dan rating yang telah ditentukan sebelumnya, serta dapat mengantisipasi hal yang tidak diinginkan ketika sistem tidak beroperasi secara normal, sehingga dapat 
ditentukan perlakuan khusus untuk menjaga sistem tetap normal. Objek monitoring yang akan dilakukan adalah untuk memantau arus dan tegangan dari sebuah power supply yang memasok listrik menuju sebuah motor DC yang diatur menggunakan sebuah variable rheostat atau resistor variabel pada Simulator PLN yang berada pada Laboratorium Teknik Tenaga Listrik, Departemen Teknik Elektro dan Informatika, Sekolah Vokasi, Universitas Gadjah Mada, alat monitor ini diberi nama Smart DC Current Voltage monitoring, dimana kata smart merupakan pencerminan kemajuan teknologi, dimana kebutuhan manusia dapat dikerjakan dengan menggunakan gadget dengan sistem yang terkoneksi dengan internet atau online. Monitoring dibuat dengan berbasis mikrokontroler Arduino Mega 2560, yang digunakan untuk pemroses data sensor berupa sensor arus ACS 71220 B yang digunakan sebagai sensor arus dengan rating arus 20 Ampere dan sensor tegangan dengan rating tegangan 220 Volt. Output dari sensor merupakan data digital yang selanjutnya akan diolah menggunakan Arduino Mega 2560yang dibuat bertujuan untuk memonitor arus dan tegangan DC pada kerja suatu beban DC, pada simulator PLN di Laboratorium Teknik Ketenagaan Listrik. Dari data yang nantinya didapatkan akan diketahui seberapa optimal kerja dari alat untuk memonitor kerja motor DC. Hasil pengukuran menggunakan sensor arus ACS 71220 B dan voltage divider sebagai sensor tegangan. Hasil pengukuran akan diproses pada mikrokontroller Ardino Mega 2560 dengan rumus yang telah ditentukan dan dilakukan kalibrasi, sehingga data dapat dimanfaatkan. Data dari Arduino Mega 2560 akan ditransmisikan menuju modul WiFi Nodemcu ESP 8266 melalui pin UART(PIN RX, PIN TX) antar mikrokontroler atau biasa disebut dengan sistem komunikasi data serial, ketika telah saling terhubung dan berkomunikasi dalam hal ini Modul WiFi Nodemcu ESP 8266 dapat menerima data dari Arduino Mega yang dapat di pantau menggunakan serial monitor yang telah disediakan pada aplikasi Arduino IDE. Setelah dapat menerima data dan saling berkomunikasi, Modul WiFi harus di hubungkan pada koneksi internet yang telah di sediakan sebelumnya. Setelah itu data dapat di transmisikan menuju sebuah web server sebagai pengumpul data dengan platform yang dipilih yaitu thingspeak. Hal yang perlu dilakukan untuk mengakses data pada platform Thingspeak adalah mendaftarkan akun melalui alamat email yang kita miliki, setelah terdaftar dan memiliki akun sendiri kita dapat menginputkan data melalui field Thingspeak yang digunakan untuk menerima data dari Modul WiFi Nodemcu ESP 8266. Hasil pengukuran dapat dipantau melalui Thingspeak dengan login akun Thingspeak terlebih dahulu.

Kata kunci-Smart DC current voltage monitoring, Simulator PLN, ACS 71220 B, Sensor Tegangan, Mikrokontroler, Thingspeak

\section{Pendahuluan}

Sinkronisasi sumber tegangan PLN dan Grid merupakan kegiatan menggabungkan dua sumber teganan yaitu dari generator dengan sumber PLN dengan menyamakan tegangan, frekuensi dan urutan fase pada generator karena sumber PLN tidak bisa mengatur tegangan dan frekuensi, hal yang dilakukan dalam sinkronisasi adalah memparalelkan generator antara generator PLN dengan generator grid, dengan tujuan untuk menjaga kontinuitas pelayanan tenaga listrik apabila salah satu generator diistirahatkan atau diperbaiki serta untuk memperbesar kapasitas daya yang dihasilkan.

Bila dua sistem tegangan bolak-balik (AC) akan diparalel, maka kesamaan dari kondisi atau parameter berikut ini harus dipenuhi oleh tegangan, frekuensi dan urutan Fase. Untuk urutan fase mengacu dimana fase $\mathrm{R}$ terhubung dengan fase $\mathrm{R}$ dalam sinkronisasi 2 buah generator, $\mathrm{S}$ terhubung $\mathrm{S}$ dan $\mathrm{T}$ terhubung $\mathrm{T}$ skema rangkaian sinkronisasi 2 buah generator seperti tampak pada Gambar 1.

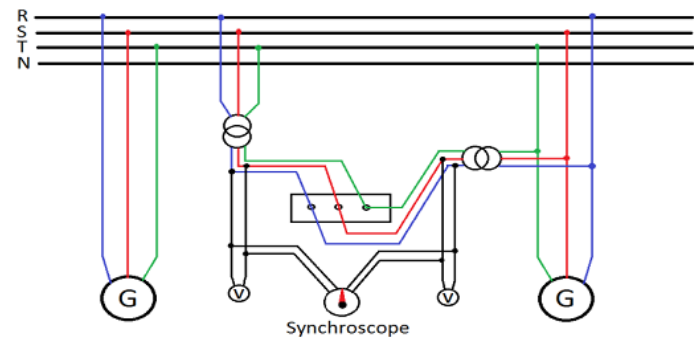

Gambar 1. Sinkronisasi Sumber Tegangan PLN dan Grid
Metode yang dilakukan dalam sinkronisasi adalah Metode gelap dan Metode Terang. Jenis sinkronisasi gelap, sebagaimana ditunjukkan oleh Gambar 2, menggunakan prinsip dengan menghubungkan antara ketiga fase, yaitu $U$ terhubung $\mathrm{U}, \mathrm{V}$ terhubung $\mathrm{V}$ dan $\mathrm{W}$ terhubung $\mathrm{W}$.

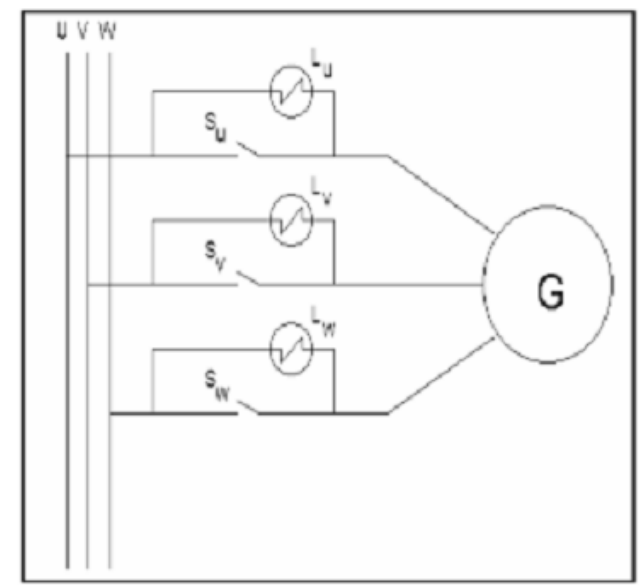

Gambar 2. Sinkronisasi Metode Gelap

Pada hubungan ini jika tegangan antar fase adalah sama maka ketiga lampu akan gelap yang disebabkan oleh beda tegangan yang ada adalah nol. Demikian juga sebaliknya, jika lampu menyala maka diantara fase terdapat beda tegangan. Jenis sinkronisasi lampu terang yang disajikan pada Gambar 3 menggunakan prinsip menghubungkan antara ketiga fase, yaitu $\mathrm{U}$ terhubung $\mathrm{V}, \mathrm{V}$ terhubung $\mathrm{W}$ dan $\mathrm{W}$ terhubung $\mathrm{U}$. 
Sinkronisasi jenis ini merupakan kebalikan dari sinkronisasi lampu gelap. Jika antara fase terdapat beda tegangan maka ketiga lampu akan menyala sama terang dan generator siap untuk diparalel. Kelemahan dari sinkronisasi ini adalah kita tidak mengetahui seberapa terang lampu tersebut sampai generator siap diparalel.

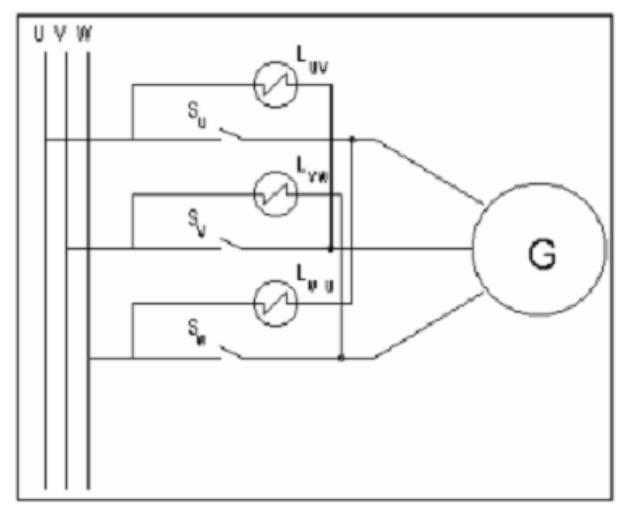

Gambar 3. Sinkronisasi Metode Terang

Peralatan atau komponen yang digunakan dalam pembuatan DC Current Voltage Monitoring berbasis mikrokontroler pada sinkronisasi generator atau simulator PLN dengan sumber PLN 3 fase skala laboratorium yaitu seperti yang tertera pada Tabel I.

Tabel 1. Komponen sistem

\begin{tabular}{|c|c|c|}
\hline No & Nama Alat & Jumlah \\
\hline 1 & Variable DC Power Supply & 1 buah \\
\hline 2 & Motor DC Shunt & 1 buah \\
\hline 3 & Resistor Variabel & 2 buah \\
\hline 5 & Arduino Mega 2560 & 1 Buah \\
\hline 6 & Nodemcu ESP 8266 & 1 buah \\
\hline 7 & ACS 712 20B & 1 buah \\
\hline 8 & Resistor 10 W $100 \mathrm{~K}$ & 1 buah \\
\hline 9 & Resistor 10 W $1 \mathrm{~K}$ & 2 buah \\
\hline 10 & Kapasitor Polar 470 V 33 uF & 1 buah \\
\hline
\end{tabular}

Variable DC Power Supply merupakan sebuah catu daya yang mengalirkan listrik ke sebuah rangkaian beban. Variabel DC Power Supply juga sering disebut sebagai rectifier, yang mana cara kerjanya mengkonversi jenis aliran listrik AC menjadi DC sebagaimana tampak pada Gambar 4.

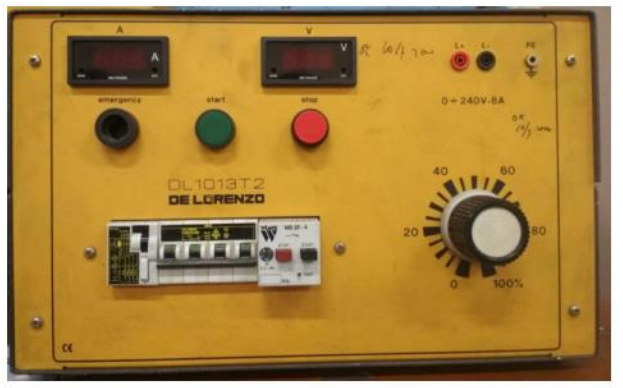

Gambar 4. Variable DC Power Supply

Mesin listrik memiliki dua fungsi yaitu sebagai motor dan sebagai generator. Untuk jenis motor dan generator ada dua yaitu DC dan AC. Motor listrik bekerja dengan cara mengubah tenaga listrik menjadi tenaga mekanik, untuk generator bekerja dengan cara mengubah tenaga mekanik menjadi tenaga listrik. Pada modul sinkronisasi ini motor listik DC difungsikan sebagai pemutar generator.

Terdapat dua bagian utama pada sebuah Motor Listrik $D C$ Shunt yaitu stator dan rotor. Stator adalah bagian motor yang tidak berputar, bagian yang statis ini terdiri dari rangka dan kumparan medan. Sedangkan rotor adalah bagian yang berputar, bagian rotor ini terdiri dari kumparan jangkar. Dua bagian utama ini dapat dibagi lagi menjadi beberapa komponen penting yaitu diantaranya adalah yoke (kerangka magnet), poles (kutub motor), field winding (kumparan medan magnet), Armature Winding (kumparan jangkar), commutator (komutator) dan brushes (kuas/sikat arang).

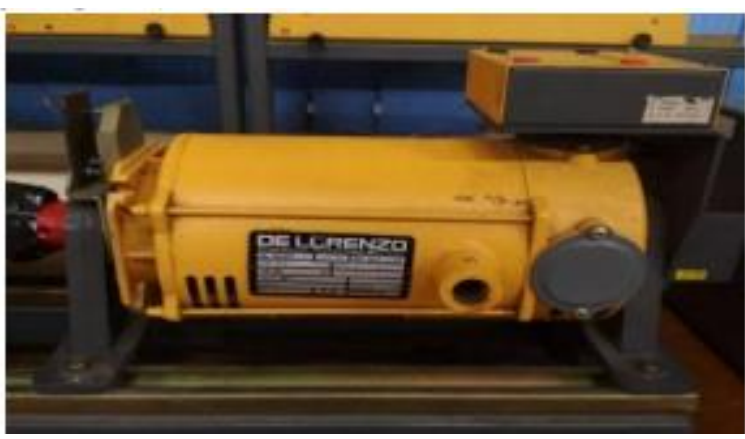

Gambar 5. Bentuk Fisik Motor Shunt DC

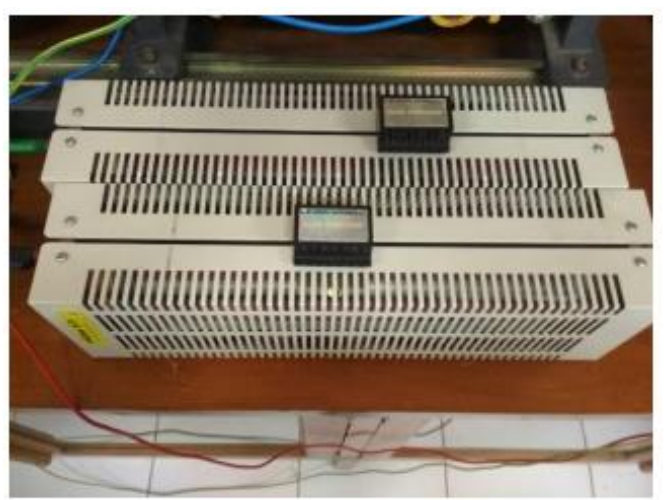

Gambar 6. Bentuk Fisik Resistor Variabel 
Rheostat seperti tampak di Gambar 6 adalah resistor variabel yang digunakan untuk mengontrol arus yang mengalir dalam rangkaian atau sirkuit. Rheostat adalah salah satu jenis potensiometer yang memiliki 2 kawat kaki untuk koneksi. Rheostat (hambatan geser) merupakan resistor variabel yang didesain untuk menangani arus dan tegangan yang tinggi. Oleh karena itu sebagian besar rheostat didesain seperti resistor gulungan kawat (wirewound). Komponen ini berfungsi sebagai hambatan yang dapat diatur nilai hambatannya. Bisa diaplikasikan menjadi beban seperti barang elektronik. Komponen ini juga dapat dihubungkan secara seri maupun parallel.

Rheostat sering digunakan sebagai perangkat kontrol daya, misalnya untuk mengontrol atau mengatur intensitas cahaya (dimmer), kecepatan motor, pemanas dan oven. Namun sekarang rheostat tidak digunakan dalam fungsi ini lagi dikarenakan efisiensinya yang relatif rendah. Sebagai resistor variabel rheostat sering digunakan untuk tuning dan kalibrasi pada sirkuit. Dalam kasus ini rheostat disetel/ disesuaikan hanya selama fabrikasi atau penyetelan sirkuit/ rangkaian (preset resistor).

Arduino Mega 2560 adalah papan pengembangan mikrokontroler yang berbasis Arduino dengan menggunakan chip ATmega 2560. Modul papan Arduino Mega 2560 dilengkapi dengan sebuah oscillator $16 \mathrm{MHz}$, sebuah port USB, power jack DC, ICSP header, dan tombol reset. Gambar 7 menunjukkan bentuk fisik modul papan Arduino Mega 2560.

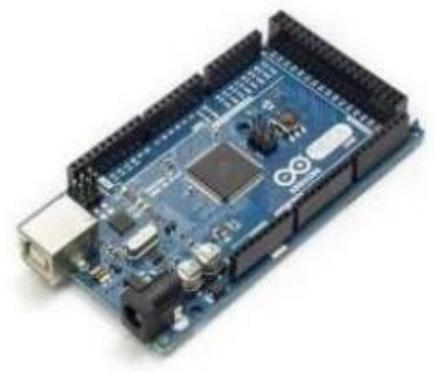

Gambar 7. Arduino Uno

Pada modul papan Arduino Mega 2560 menggunakan bahasa $\mathrm{C}$ sebagai bahasa pemrograman serta Arduino IDE sebagai compiler. Modul papan Arduino Mega 2560 memiliki pin input/output (I/O) sebanyak 54 pin digital dengan 15 pin diantaranya adalah PWM, 16 pin analog input dan 4 pin komunikasi serial.

NodeMCU merupakan sebuah open source platform IoT dan pengembangan kit yang menggunakan bahasa pemrograman Lua untuk membantu dalam membuat prototipe produk IoT atau bisa dengan memakai sketch dengan Arduino IDE.

Pengembangan kit ini didasarkan pada modul ESP8266, yang mengintegrasikan GPIO, PWM (Pulse Width Modulation), IIC, 1-Wire dan ADC (Analog to Digital Converter) semua dalam satu board. GPIO NodeMCU ESP8266 seperti Gambar 8.

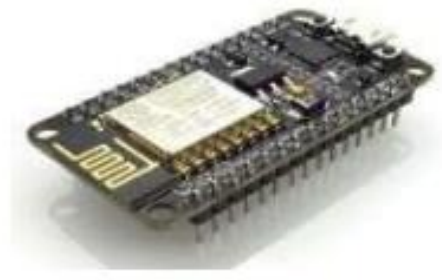

Gambar 8. Nodemcu ESP 8266

NodeMCU berukuran panjang $4.83 \mathrm{~cm}$, lebar $2.54 \mathrm{~cm}$, dan berat 7 gram. Board ini sudah dilengkapi dengan fitur WiFi dan Firmware yang bersifat opensource.

ACS 71220 B merupakan sebuah sensor arus yang digunakan untuk merasakan dan mengendalikan aliran arus adalah persyaratan mendasar dalam berbagai aplikasi termasuk, sirkuit perlindungan arus berlebih, pengisi daya baterai, catu daya mode switching, meter watt digital, sumber arus yang dapat diprogram, dll. Modul arus ACS721 ini didasarkan pada sensor ACS712, Yang secara akurat dapat mendeteksi arus AC atau DC. AC atau DC maksimum yang dapat dideteksi dapat mencapai 20A, dan sinyal saat ini dapat dibaca melalui port I / O analog Arduino. Ada juga versi 5A dan 30A sebagai pilihan lain sesuai rating arus yang diperlukan. gambar ACS 71220 B dapat di gambarkan sebagai berikut pada gambar 9 .

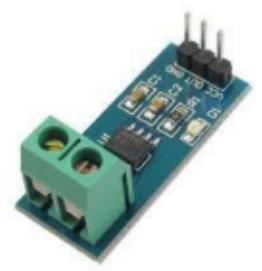

Gambar 9. ACS 71220 B

Voltage Sensor atau sensor tegangan yang kami gunakan dalam pembuatan alat ini menggunakan konsep pembagi tegangan, dikarenakan beberapa modul yang digunakan semisal sensor voltage hanya memiliki range tegangan sebesar $25 \mathrm{~V}$ padahal input sumber yang digunakan dalam sistem monitoring yaitu mencapai 250 VDC yang termasuk HVDC, berikut skematik dari pembagi tegangan yang digunakan adalah pada gambar 10 .

Pada Gambar 10 merupakan gambar dari sensor tegangan dimana sensor menggunakan prinsip pembagi tegangan, pembagi tegangan berfungsi untuk menurunkan tegangan tinggi menjadi tegangan yang dapat masuk atau sesuai rating.

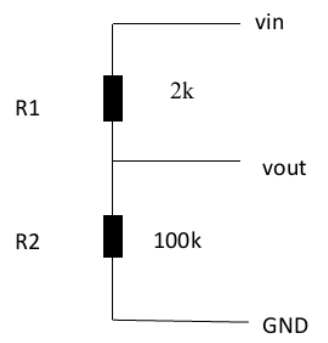

Gambar 10. Sensor Tegangan 
Tegangan kerja dari Arduino atau mikrokontroler sebagai pemroses data sensor, sehingga nilai tegangan yang masuk dapat dilihat dan dimanfaatkan manusia. Komunikasi Data Serial (serial communications) merupakan cara pengiriman data yang lebih mudah dibandingkan komunikasi paralel (parallel communications) disebabkan sistem komunikasi paralel terlalu mahal untuk kegunaan jarak jauh. Data yang bernilai 8 bit di simpan di shift register dan dikirim secara satu bit demi satu bit ke tujuannya. Biasanya shift register tersebut berbentuk sebuah IC yang digunakan khas untuk komunikasi serial yang disebut UART (Universal Asynchronous Receiver Transmitter).

UART juga terdapat pada mikrokontroler baik Arduino maupun NodemCu ESP 8266, pada pin rx dan tx pada mikrokontroler, disambungkan pada Gambar 11.

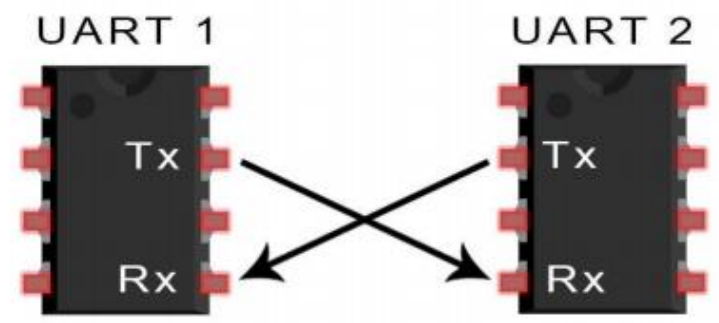

Gambar 11. Sistem Komunikasi Data Serial

Arduino IDE adalah sebuah perangkat lunak yang memudahkan untuk melakukan pengembangan aplikasi mikrokontroler mulai dari menuliskan source program kompilasi, unggah hasil kompilasi, dan uji coba secara terminal serial. Arduino IDE ini dapat dijalankan di komputer atau laptop dengan berbagai macam platform karena Arduino IDE ini berbasis Java. Source program yang digunakan untuk pembuatan aplikasi mikrokontroler adalah menggunakan bahasa $\mathrm{C} / \mathrm{C}++$ dan dapat digabung dengan bahasa assembly. Gambar 12 merupakan tampilan dari Arduino IDE.

Program yang ditulis dengan menggunakan Arduino IDE disebut sebagai sketch. Sketch ditulis dalam suatu editor teks dan disimpan di dalam file dengan ekstensi.ino. teks editor pada Arduino IDE memiliki fitur-fitur seperti cutting atau paste dan searching atau replacing sehingga memudahkan pengguna dalam menulis kode program. Pada software Arduino IDE, terdapat semacam message box berwarna hitam yang berfungsi menampilkan status, seperti pesan error, compile, dan unggah program. Di bagian bawah paling kanan software Arduino IDE, menunjukkan board yang terkonfigurasi dengan komputer beserta COM masukan port yang digunakan.

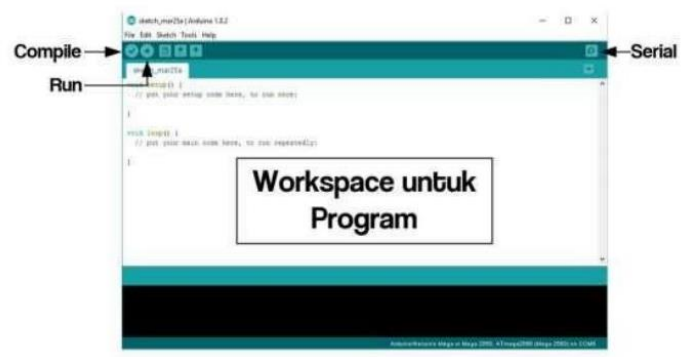

Gambar 12. Software Arduino IDE
Thingspeak merupakan open source internet of things aplikasi untuk menyimpan dan mengambil data dari hal-hal yang menggunakan HTTP melalui internet atau melalui local area network. Fitur dari Thingspeak adalah sebagai berikut.

- Open API

- Real-time data collection

- Geolocation data

- Data processing

- Data visualizations

- Device status messages

- Plugins

Internet of Things (IoT) menyediakan akses ke berbagai perangkat terhubung dan layanan web. Thingspeak adalah platform IoT yang memungkinkan untuk mengumpulkan, menyimpan, menganalisis, memvisualisasikan, dan bertindak atas data dari sensor atau aktuator, seperti Arduino, Raspberry $\mathrm{Pi}$, BeagleBone Hitam, dan perangkat keras lainnya. Misalnya, dengan Thingspeak kita dapat membuat aplikasi sensorlogging, aplikasi pelacakan lokasi. Thingspeak berfungsi sebagai pengumpul data yang mengumpulkan data dari perangkat node dan juga memungkinkan data yang akan diambil ke dalam lingkungan perangkat lunak untuk analisis historis data.

Simulator PLN merupakan pensimulasian sinkronisasi antara grid dengan sumber tegangan PLN, adapun cara pensinkronisasian dengan menggabungkan dua sumber teganan yaitu dari generator dengan sumber PLN dengan menyamakan tegangan, frekuensi dan urutan fase pada generator karena sumber PLN tidak bias mengatur tegangan dan frekuensi, berikut gambar konstruksi dari skema sinkronisasi grid dengan PLN.

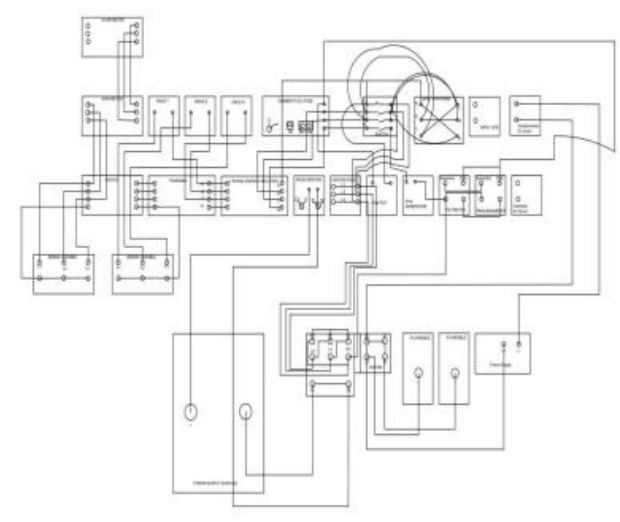

Gambar 13. Skema Smulator PLN

Paralel generator adalah metode penggunaan dua atau lebih generator secara bersamaan yang dihubungkan secara paralel. Pararel generator ini bertujuan untuk menjaga kontinuitas pelayanan tenaga listrik apabila salah satu generator akan diistirahatkan atau diperbaiki dan untuk memperbesar kapasitas daya yang dihasilkan.

Objek pengamatan pada proyek monitoring tegangan dan arus pada simulator PLN menggunakan beberapa part atau komponen yang digunakan dalam system simulator PLN, yaitu dibutuhkan power supply, rheostat, dan motor DC, dapat digambarkan pada rangkaian Gambar 14. 


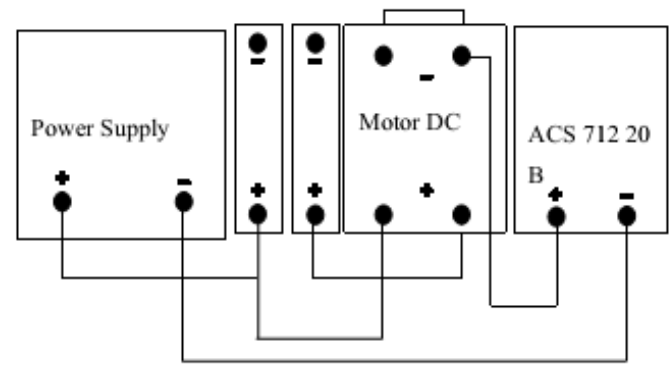

Gambar 14. Objek Penelitian

Pemantauan tegangan dan arus dilakukan pada sebuah power supply sebagai Sumber listrik, pemutar generator pada simulator PLN menggunakan motor dengan tegangan DC sebagai penggerak utama, besar kecilnya keluaran atau output dari generator sangat dipengaruhi oleh kecepatan putar motor, sehingga dapat dikatakan sangat perlu dalam pemantauan arus dan tegangan pada penggerak utama simulator PLN sehingga didapatkan data yang akurat secara berkala waktu ke waktu.

Media transmisi data yang digunakan yaitu dengan menggunakan Nodemcu ESP 8266, dengan menggunakan prinsip kerja komunikasi data serial, atau disebut software serial untuk pengiriman data dari pemroses data sensor yaitu Arduino Mega 2560 menuju ESP 8266 sebagai media transmisi yang selanjutnya dikirim menuju website thingspeak.com sebagai media pengumpul data, sehingga dapat di lihat gambar sistematik cara mendapatkan data sampai pengiriman data dapat dilihat pada Gambar 15.

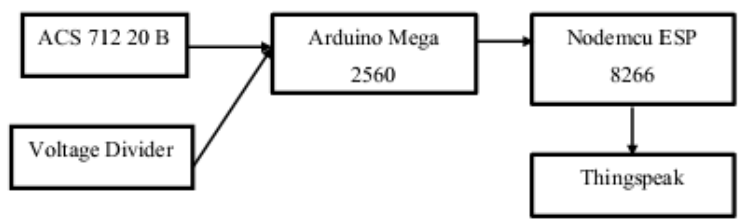

Gambar 15. Sistematik cara kerja alat

\section{HASIL}

Kalibrasi perangkat dilakukan sebelum memantau data arus dan data tegangan dalam peralatan monitoring DC.

\section{a. Kalibrasi Power Supply}

Power Supply merupakan perangkat elektronik sebagai penyuplai tegangan DC dan tentunya power supply ini bertugas untuk menyuplai tegangan DC menuju peranti peranti elektronik dengan input tegangan DC, dalam hal ini Motor DC. Data kalibrasi power supply ditampilkan pada Tabel II.

Metode yang digunakan untuk pengujian adalah menggunakan pengujian maju yaitu dengan mengulang percobaan selama $5 \mathrm{kali}$, dimana pada setiap penambahan skala (\%) power supply akan diberi waktu tunda selama 1 menit, sehingga didapatkan data kalibrasi power supply yang presisi, sebagai salah satu langkah kerja untuk mengetahui keandalan dari power supply itu sendiri sebagai penyuplai utama tegangan DC pada simulator PLN.

Tabel 2. Data kalibrasi power supply

\begin{tabular}{|c|c|c|c|c|c|c|c|}
\hline \multirow{2}{*}{ No. } & \multirow{2}{*}{ skala(\%) } & \multicolumn{7}{|c|}{ Pengujian Maju(V) } & \multirow{2}{*}{ Rerata } \\
\cline { 3 - 7 } & & 1 & 2 & 3 & 4 & 5 & \\
\hline 1 & $0 \%$ & 2 & 2 & 2 & 2 & 2 & 2 \\
\hline 2 & $10 \%$ & 26 & 26 & 26 & 26 & 26 & 26 \\
\hline 3 & $20 \%$ & 51 & 51 & 51 & 51 & 51 & 51 \\
\hline 4 & $30 \%$ & 77 & 77 & 77 & 77 & 77 & 77 \\
\hline 5 & $40 \%$ & 102 & 102 & 102 & 102 & 102 & 102 \\
\hline 6 & $50 \%$ & 129 & 129 & 129 & 129 & 129 & 129 \\
\hline 7 & $60 \%$ & 156 & 156 & 156 & 156 & 156 & 156 \\
\hline 8 & $70 \%$ & 183 & 183 & 183 & 183 & 183 & 183 \\
\hline 9 & $80 \%$ & 210 & 210 & 210 & 210 & 211 & 210,2 \\
\hline 10 & $90 \%$ & 235 & 235 & 235 & 235 & 235 & 235 \\
\hline 11 & $10 \% \%$ & 261 & 261 & 261 & 261 & 263 & 261,4 \\
\hline
\end{tabular}

Dari data di atas rating tegangan yang digunakan untuk menyuplai motor DC adalah $190 \mathrm{~V}$, atau sekitar skala $70 \%$ pada knob putar power supply, hal ini dikarenakan motor DC memiliki rating tegangan maksimum yaitu 190 Volt. Data ini juga digunakan untuk mengetahui keandalan dari output power supply, hal ini dapat dilihat dengan dilakukannya pengukuran maju sebanyak 5 kali, setelah itu akan didapatkan rerata tegangan keluaran tiap penambahan skala pada power supply yang menunjukkan perangkat tersebut bisa digunakan.

\section{b. Kalibrasi dan Pengukuran Resitor Variabel Geser}

Tabel 3. Data resistansi Rheostat

\begin{tabular}{|c|c|c|}
\hline \multicolumn{3}{|c|}{ RESISTANSI RESISTOR VARIABEL DLIN PRN 322 F } \\
\hline NO & $\begin{array}{c}\text { JUMLAH PENGGESERAN } \\
\text { (BARIS) }\end{array}$ & RESISTANSY(Ohm) \\
\hline 1 & 5 & 40 \\
\hline 2 & 10 & 120 \\
\hline 3 & 15 & 160 \\
\hline 4 & 20 & 200 \\
\hline 5 & 25 & 320 \\
\hline 6 & 30 & 400 \\
\hline 7 & 35 & 480 \\
\hline 8 & 40 & 550 \\
\hline 9 & 45 & 650 \\
\hline 10 & 50 & 800 \\
\hline
\end{tabular}

Resistor Variabel merupakan Rheostat adalah resistor variabel yang digunakan untuk mengontrol arus yang mengalir dalam rangkaian atau sirkuit. Rheostat adalah salah satu jenis potensiometer yang memiliki 2 kawat kaki untuk koneksi. Rheostat (hambatan geser) merupakan resistor variabel yang didesain untuk menangani arus dan tegangan yang tinggi. Oleh karena itu sebagian besar rheostat didesain seperti resistor gulungan kawat (wirewound). Berikut data hasil pengukuran resistansi Resitor Variabel

Dengan data hasil pengukuran $\mathrm{R}$ variabel seperti di Tabel II bisa menentukan besaran arus yang keluar dari beban resistor variabel, dapat diketahui bahwa semakin besar perpindahan tuas pada resistor variabel maka semakin besar pula hasil pengukuran $\mathrm{R}$ variable.

Data resistansi tersebut diambil dengan cara menghubungkan multimeter pada ujung pangkal rheostat, lalu 
dilakukan penggeseran knob rheostat, dikarenakan tidak ditemukan parameter yang digunakan untuk mengukur, maka di pakailah baris atau sela rheostat, dengan setiap penambahan baris yaitu 5 baris, sampai 50 baris, didapatkan data seperti tertampil pada Tabel II, kisaran nilai resistansi berjenjang dari $40 \mathrm{Ohm}-800 \mathrm{Ohm}$, dkarenakan peran rheostat sebagai pembatas arus yang masuk menuju motor DC, dan juga sebagai pengatur kecepatan motor, maka data tersebut sangat penting dalam membantu proyek ini.

c. Pengukuran arus dengan menggunakan beban resistor variabel

Pengukuran arus menggunakan rheostat dilakukan mengetahui besaran arus yang masuk motor DC data hasil pengukuran akan ditampilkan pada Tabel IV.

Pada pengukuran arus dilakukan dengan cara menghubungkan power supply, atau penyupai tegangan DC pada resistor variabel, dengan dihubungkan dengan amperemeter, setelah itu maka diubah ubah besaran tegangan power supply dan resistor variabel atau rheostat.

Pengukuran dilakukan sekali dengan tiap penambahan skala geser dengan jeda 1 (satu) menit, di dapatkan hasil seperti tertampil pada tabel diatas, pada skala geser 0 baris dengan input power supply $30 \%-100 \%$, tidak didapatkan data karena ketika tidak terdapat beban atau dengan rheostat yang memiliki skala baris yang kecil dan sumber tegangan yang besar maka akan terjadi arus lebih atau overcurrent, hal ini dapat menyebabkan rusaknya amperemeter dikarenakan range arus yang digunakan adalah $5 \mathrm{~A}$, sehingga dapat dikatakan arus yang keluar melebihi rating $5 \mathrm{~A}$.

Tabel 4. Data pengukuran arus dengan beban $\mathrm{R}$ variabel

\begin{tabular}{|r|c|r|r|r|r|r|r|}
\hline \multirow{2}{*}{ No. } & Skala Power & \multicolumn{6}{|c|}{ Anus Pada Beban Variabel(A) } \\
\cline { 3 - 8 } & Supply(\%) & 0 baris & 10 baris & 20 baris & 30 baris & 40 baris & 50 baris \\
\hline 1 & 0 & 0,20 & 0,00 & 0,00 & 0,00 & 0 & 0 \\
\hline 2 & 10 & 0,10 & 0,25 & 0,10 & 0,10 & 0,05 & 0,05 \\
\hline 3 & 20 & 0,50 & 0,50 & 0,25 & 0,15 & 0,10 & 0,10 \\
\hline 4 & 30 & - & 0,80 & 0,30 & 0,20 & 0,20 & 0,15 \\
\hline 5 & 40 & - & 1,00 & 0,50 & 0,30 & 0,20 & 0,20 \\
\hline 6 & 50 & - & 1,25 & 0,60 & 0,40 & 0,30 & 0,30 \\
\hline 7 & 60 & - & 1,00 & 0,70 & 0,45 & 0,35 & 0,30 \\
\hline 8 & 70 & - & 1,75 & 0,85 & 0,50 & 0,40 & 0,40 \\
\hline 9 & 80 & - & 2,00 & 0,90 & 0,55 & 0,50 & 0,50 \\
\hline 10 & 90 & - & 2,25 & 1,00 & 0,60 & 0,55 & 0,55 \\
\hline 11 & 100 & - & 2,50 & 1,50 & 0,70 & 0,60 & 0,60 \\
\hline
\end{tabular}

\section{d. Pengujian Sensor Tegangan}

Sensor tegangan diuji dengan menggunakan prinsip pembagi tegangan. Langkah ini merupakan langkah untuk menurunkan tegangan DC sehingga tegangan tinggi DC atau HVDC yang berasal dari power supply dapat diturunkan dan diukur serta dapat diproses menggunakan mikrokontroler Arduino Mega 2560 yang memiliki tegangan kerja 5 Volt.

$$
\begin{aligned}
& \text { Vout }=\frac{R 2}{R 1+R 2} X \text { Vin } \\
& \text { Vout }=\frac{2000 \Omega}{1000 \Omega+R 2 \Omega} X \text { Vin }
\end{aligned}
$$

Vout $=4.23$ Volt
Dengan perhitungan menggunakan sistem pembagi tegangan maka didapatkan bahwa ketika masukan power supply yaitu $220 \mathrm{~V}$ maka sistem pembagi tegangan akan ditransformasikan tegangan menjadi $4.23 \mathrm{~V}$ maksimal, sehingga data dapat langsung masuk menuju pin analogRead melalui mikrokontroler Arduino Mega 2560 sehingga data diolah menjadi data sesuai dengan rumus yang telah ditentukan.

Data nilai tegangan yang dapat diterima harus menggunakan rumus seperti diatas, pembacaan ADC dari Arduino 10bit dimana pembacaan adc dimulai dari 0-1023, yang menandakan tegangan dimulai dari $0-5$ Volt. Angka 52 merupakan konstanta yang digunakan untuk menampilkan data real dimana tegangan maksimum yang dapat diterima Arduino sebagai tegangan kerja yaitu 5 Volt, keluaran dari sensor tegangan adalah 4.23 Volt, sehingga perlu dikalikan dengan 52, dimana $4.23 \times 52=220$, sehingga angka 4.23 Volt yang diterima Arduino merupakan representasi dari sumber tegangan power supply 220 Volt.

\section{e. Pengujian Sensor Arus ACS 71220 B}

ACS 71220 B merupakan sensor arus AC dan DC, sensor ACS 71220 B memiliki rating arus 20 Ampere, hal ini digunakan untuk mendeteksi atau mensensor arus pada suatu sistem kelistrikan, sistem kerjanya yaitu mengambil inputan atau masukan plus dari akhir beban, dan inputan negatif berasal dari polaritas minus sumber tegangan misal power supply, seperti pada digambarkan pada Gambar 16.

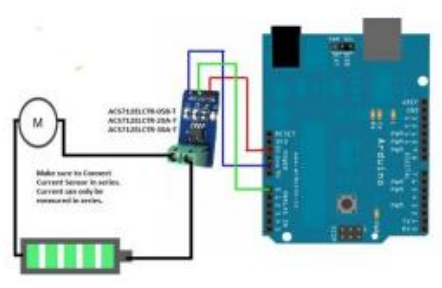

Gambar 16. ACS 71220 B

Data arus yang diambil akan diproses menggunakan mikrokontroler yaitu Arduino Mega 2560 dengan menggunkan program Arduino sebagai gambar 17 berikut.

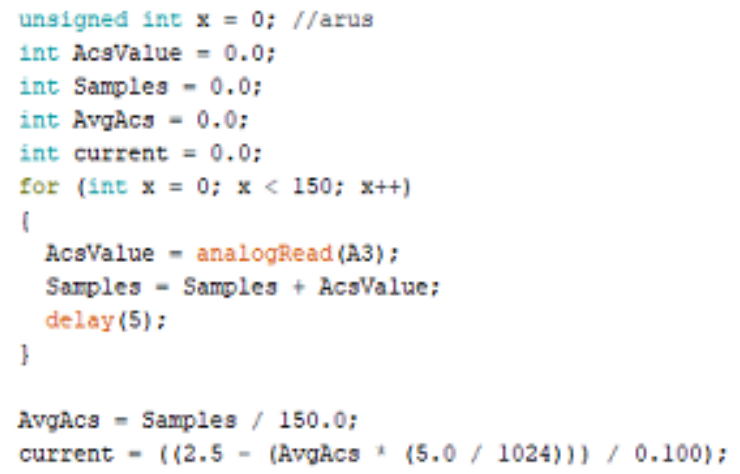

Gambar 17. Program Arduino pembacaan sensor arus 
Pada pembacaan sensor arus harus menggunakan pembacaan perulangan sebanyak 150 kali untuk mendapatkan hasil yang tidak fluktuatif, kita tahu bahwa arus pada beban motor akan menghasilkan data pengukuran data yang fluktatif, sehingga dengan cara digunakan untuk meminimalisir data fluktuatif tersebut.

Hasil pembacaan sebanyak 150 kali akan dijadikan sampel, yang kemudian akan direrata dengan dibagi jumlah data yaitu 150 , untuk mengubah data adc menjadi analog maka rumus current seperti terdapat pada gambar, digunakan untuk mengubah data digital menjadi data analog, data akan di sensor menggunakan pin Analogread 0 (A3), dengan rumus yang telah ditentukan sesuai data sheet.

\section{f. Pengujian ESP Nodemcu 8266}

Pada perancangan alat ini NodeMCU berperan sebagai pengirim informasi dari hardware menuju website melalui jaringan Wi-Fi dari sebuah router.

Pengujian NodeMCU dilakukan untuk mengetahui apakah modul yang digunakan dapat bekerja dengan baik. Maka dari itu perlu ada pengujian apakah NodeMCU yang dipakai masih bisa berfungsi secara baik atau tidak, dapat ditampilkan pada Gambar 4.8 sebagai berikut.

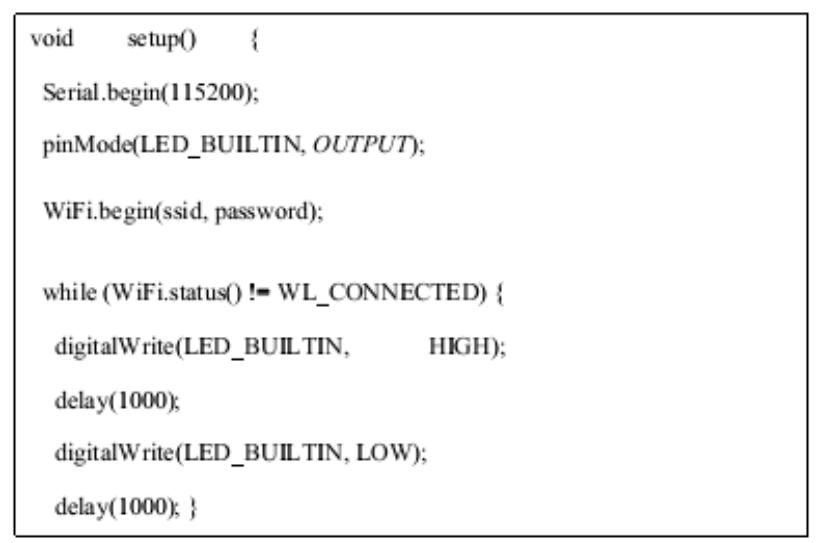

Gambar 18. Program Kalibrasi Nodemcu ESP 8266

Hasil pengujian dari program pada gambar 18 ditunjukkan oleh gambar 19 dan dapat diketahui bahwa ketika Nodemcu sudah mendapat acces hotspot internet dari sebuah router maka Nodemcu akan timbul blink atau kedip pada LED sebagai reaksi Nodemcu ketika suda terkoneksi dengan Hotspot WiFi internet yang telah disediakan dan dapat dipantau melalui serial monitor.

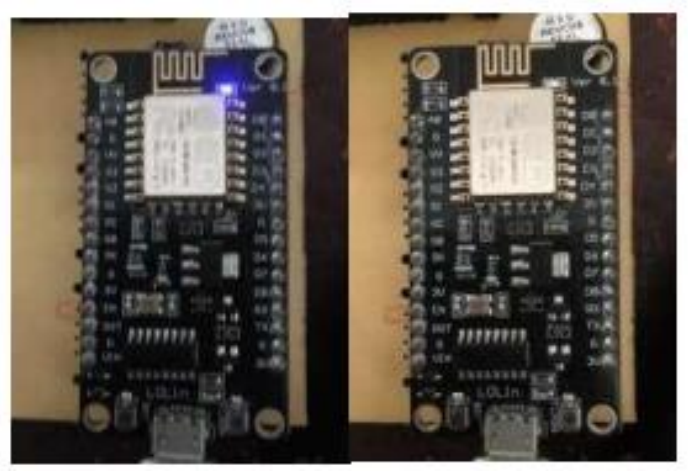

Gambar 19. Hasil Kalibrasi Nodemcu ESP 8266

\section{g. Pengujian Komunikasi data serial}

Komunkasi data serial dilakukan dengan cara menyambungkan pin serial RX dan TX pada masing masing mikrokontroler yaitu Arduino Mega 2560 dan pin RX TX pada Nodemcu ESP 8266. Pada komunikasi data serial, misalkan UART 1 merupakan Pin RX TX pada Arduino Mega 2560 dan UART 2 merupakan Pin RX, TX pada Nodemcu ESP 8266, dengan menghubungkan Pin RX UART 2 pada Pin TX UART 2, dan sebaliknya, hal ini merupakan dasar dalam melakukan komunikasi data serial.

Arduino Mega 2560 sebagai pemroses data sensor akan secara otomatis mengirimkan data, karena pin serial sudah terhubung, hal yang perlu ditambahkan adalah program pada Nodemcu ESP 8266, untuk menerima data dari Arduino Mega 2560 .

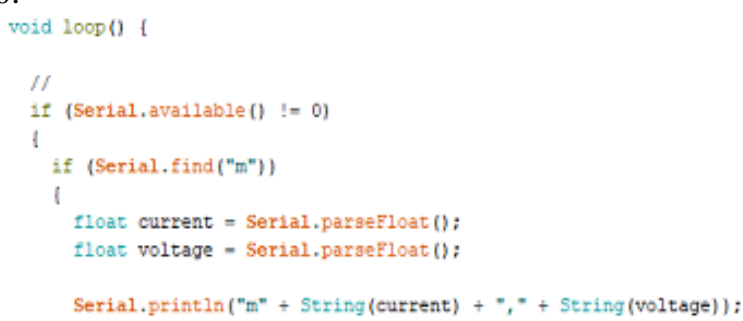

Gambar 20. Program penerimaan data Nodemcu ESP 8266

Hasil dari compiling program pada Gambar 20, dapat dilihat bahwa pengiriman data menggunakan tipe data float sehingga memungkinkan agar nilai desimal dapat dicetak, sehingga pengkuran dapat dilakukan lebih teliti, lalu program akan mencari inisial $\mathrm{m}$ pada pengiriman data arus dan tegangan, apabila berhasil maka dapat dilihat dari serial monitor sebagai pada Gambar 21 berikut.

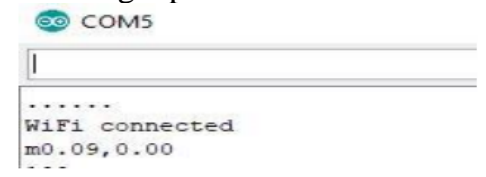

Gambar 21. Hasil Serial Monitor pengiriman data

Pada Gambar 21 tersebut dapat diketahui bahwa yang tertampil adalah m0.09,0.00, hal ini sesuai dengan program 
bahwasanya $\mathrm{m}$ adalah inisial, lalu diikuti data arus dan tegangan.

\section{h. Pengujian pengiriman data menuju Thingspeak Server}

Pada pengiriman menuju Thingspeak, ini merupakan tugas dari Nodemcu ESP 8266, sebagai modul WiFi, hal ini dngan syarat bahwa Nodemcu telah menerima hotspot dari router yang telah diberikan ssid, dan password yang sesuai pada Gambar 22, lalu program yang digunakan untuk mengirimkan data menuju thingspeak data cloud adalah sebagai berikut.

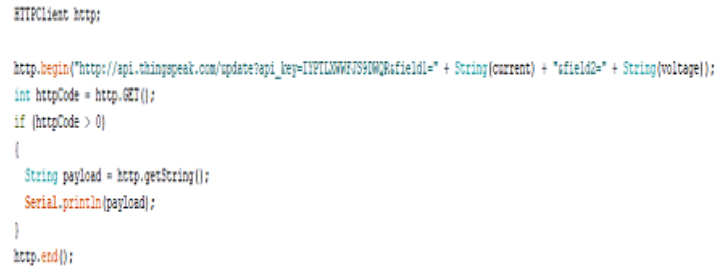

Gambar 22. Program Pengiriman data menuju Thingspeak

Hal yang perlu diinput ke program tersebut adalah nomor api key yang telah disediakan oleh thingspeak, setelah melakukan registrasi, adapun api key yang digunakan adalah IYPTLXWWFJS9DWQR, ditambah dengan field pada masing masing data sesuai dengan data yang dkirimkan, misalkan pada field 1 akan mengakomodasi data current dan field 2 akan mengakomodasi data voltage atau tegangan.

Pengujian pada Thingspeak server dilakukan dengan cara mengsuntuk mengetahui apakah nilai field pada channel Thingspeak sesuai dengan nilai data yang dikirimkan melalui NodeMCU. Pengujian dilakukan dengan cara memasukkan data field yang digunakan sesuai data yang akan di inputkan yaitu dapat digambarkan pada Gambar 23 .

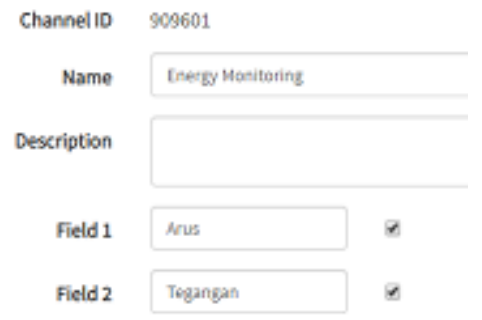

Gambar 23. Pengisian field pada server Thingspeak

Field diisikan sesuai data yang dikirim yaitu current dan voltage, agar data dapat langsung dikumpulkan melalui grafik. dan mengakses channel Thingspeak yang digunakan.

Data keluaran yang dipantau meliputi tegangan dan arus DC, berdasarkan pengukuran menggunakan Sensor Tegangan dan Sensor arus sebagai berikut berturut turut, pada Gambar 24.

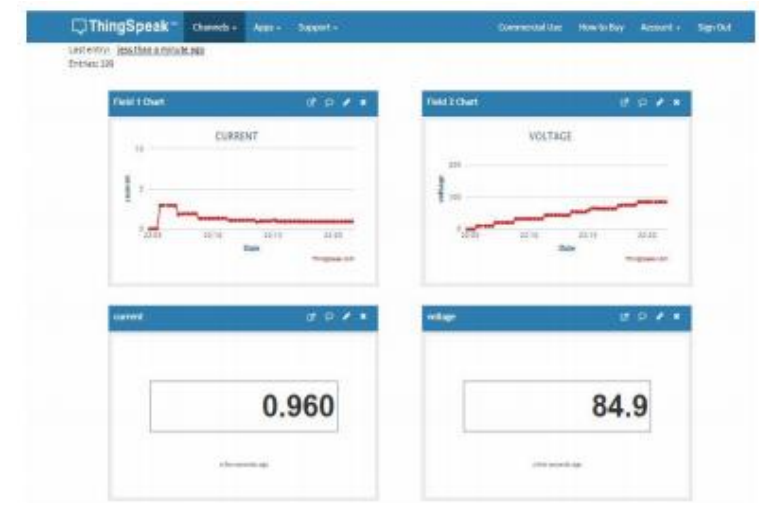

Gambar 24. Hasil pengiriman data menuju thingspeak.

Data pada Gambar 24 tersebut merupakan hasil penerimaan data yang ditransmisikan melalui modul $\mathrm{WiFi}$ Nodemcu ESP 8266 setelah, contoh dimana tegangan kerja adalah kurang lebih $85 \mathrm{~V}$ dengan beban motor variabel dan Rheostat, arus yang bekerja untuk memutar motor adalah kurang lebih 0.96 Volt.

Hal yang dapat diketahui adalah dela penerimaan data pada thingspeak adalah 15 detik, sehingga ketika pembacaan harus diberi jeda dari penerimaan data sensor melalui mikokontroler Arduino Mega 2560 sampai diterima pada platform thingspeak membutuhkan kurang lebih 15 detik.

Data akan mengikuti perubahan yang diberikan dalam hal ini putaran knob tegangan pada power supply, dan penggeseran resistor variabel atau rheostat. Data thingspeak hanya dalam bentuk grafik tegangan maupun arus terhadap wakt, yang mana ketika kita menunjuk suatu titik maka akan muncul nilai tegangan atau arus pada waktu tertentu, ditambah dengan penampilan data secara digital yang akan memudahkan kita dalam membaca data terkini suatu sistem, dalam hal ini adalah simulator PLN.

Data yang didapatkan dari pengukuran menggunakan sensor arus dan sensor tegangan yang dikirim menuju website thingspeak dapat dibaca melalui fitur penampilan data digital yang akan memudahkan kita membaca data terkini, data melalui Thingspeak secara lengkap akan ditampilkan pada Tabel V sebagai berikut.

Tabel 5. Data pengiriman data sensor menuju Thinspeak

\begin{tabular}{|c|c|c|c|c|c|c|c|c|c|c|c|}
\hline \multirow{3}{*}{ No } & \multirow{3}{*}{$\begin{array}{l}\text { VIN } \\
\text { (V) }\end{array}$} & \multicolumn{10}{|c|}{ Rheostat (Baris) } \\
\hline & & \multicolumn{2}{|c|}{0} & \multicolumn{2}{|c|}{5} & \multicolumn{2}{|c|}{10} & \multicolumn{2}{|c|}{15} & \multicolumn{2}{|c|}{20} \\
\hline & & VT & IT & $\begin{array}{ll}\text { VT } \\
\end{array}$ & IT & $\begin{array}{ll}\text { VT } \\
\end{array}$ & IT & VT & IT & VT & IT \\
\hline 1 & 10 & 10,4 & 2,96 & 10,67 & 3,06 & 10,93 & 3,3 & 10,69 & 3,36 & 10,42 & 3,43 \\
\hline 2 & 20 & 20,8 & 1,91 & 21,11 & 1,93 & 20,5 & 3,08 & 20,8 & 3,08 & 20,3 & 3,02 \\
\hline 3 & 30 & 32.5 & 1,35 & 31,02 & 1,39 & 31,1 & 1,95 & 31,5 & 2,32 & 31,52 & 2,92 \\
\hline 4 & 40 & 43,2 & 1,11 & 41,46 & 1,14 & 41,5 & 1,53 & 41,3 & 1,97 & 40,5 & 2,45 \\
\hline 5 & 50 & 53,8 & 1,01 & 51,17 & 1,01 & 51,36 & 1,28 & 51,37 & 1,57 & 51,36 & 1,91 \\
\hline 6 & 60 & 64,08 & 0,97 & 61,28 & 0,96 & 61,74 & 1,18 & 61,2 & 1,35 & 60,6 & 1,62 \\
\hline 7 & 70 & 73,7 & 0,96 & 70,2 & 0,94 & 71,7 & 1,09 & 70,98 & 1,26 & 71,21 & 1,49 \\
\hline 8 & 80 & 84,1 & 0,95 & 80,27 & 0,9 & 81,41 & 1,02 & 80,3 & 1,2 & 80,5 & 1,32 \\
\hline 9 & 90 & 92,3 & 0,98 & 90,45 & 0,86 & 91,1 & 1,01 & 90,82 & 1,12 & 91,04 & 1,29 \\
\hline 10 & 100 & 101,7 & 1 & 101 & 0,83 & 101,7 & 0,99 & 100,3 & 1,09 & 100,5 & 1,2 \\
\hline 11 & 110 & 111 & 1,04 & 111 & 0,96 & 111 & 0,98 & 110,7 & 1,07 & 111,4 & 1,19 \\
\hline 12 & 120 & 121 & 1,08 & 123,1 & 0,98 & 120,3 & 1 & 121 & 1,06 & 120,3 & 1,17 \\
\hline 13 & 130 & 131 & 1,2 & 131 & 1,03 & 130,3 & 1,01 & 130,3 & 1,05 & 131,3 & 1,15 \\
\hline 14 & 140 & 146 & 1,08 & 149 & 1,08 & 167,3 & 1,06 & 148 & 1,05 & 145,3 & 1,14 \\
\hline 15 & 150 & 160 & 1,21 & 159 & 1,11 & 158,3 & 1,08 & 158,9 & 1,06 & 157,3 & 1,13 \\
\hline 16 & 160 & 168 & 1,34 & 167 & 1,13 & 168,5 & 1,03 & 169 & 1,07 & 161,2 & 1,12 \\
\hline 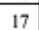 & 170 & 181 & 1.29 & 180 & 1,2 & 179,4 & 1,12 & 181,1 & 1,11 & 181,7 & 1,09 \\
\hline
\end{tabular}


Dari data diatas dapat diketahui bahwa dengan tegangan input yang sama semisal pada data nomor 17 dimana tegangan input yaitu 170 Volt dengan pengaturan beban menggunakan rheostat atau resistor geser akan menghasilkan resistansi yang semakin besar, dapat diketahui bahwa nilai arus akan turun, sesuai dengan hukum Ohm dimana nilai arus merupakan pembagian dari tegangan dibagi dengan beban dalam resistansi (Ohm) yang diberikan akan berpengaruh pada besarnya arus yang bekerja pada sistem. Nilai arus akan mengecil manakala nilai resistansi yang diberikan semakin besar sesuai dengan penambahan beban pada resistor variabel atau rheostat.

Permasalahan yang muncul adalah noise yang muncul saat penerimaan data pada thinspeak dimana masih terdapat beberapa data tegangan terkadang tidak sesuai dengan inputan yang diberikan, hal ini dikarenakan kendala dari komunikasi data serial berjalan lamban untuk mengakses data berikutnya, dan juga penerimaan data melalui thingspeak akan berjarak 15 detik untuk data selanjutnya, menyebabkan data akan sedikit berubah setelah 15 detik, penggunaan serial komunikasi memiliki profit yaitu tidak membutuhkan banyak kabel untuk komunikasi, serta dapat digunakan untuk transmisi data jarak jauh.

\section{PENUTUP}

\section{A. Kesimpulan}

Setelah melakukan perancangan, pembuatan, pengujian dan pengamatan terhadap smart DC Current Voltage Berbasis mikrokontroler Internet of Things (IoT) dengan data base cloud thingspeak pada simulator PLN skala laboratorium, maka dapat diambil kesimpulan bahwa:

1. Peranti pengukuran berupa sensor tegangan berbasis voltage divider dan sensor arus ACS 71220 B dapat bekerja secara optimal dalam melakukan sensoring data analog setelah diakukan pengujian hasil pengukuran menggunakan sensor dengan multimeter.

2. Smart DC Current Voltage Monitoring telah terintegrasi dengan data base cloud untuk menyimpan dan membaca data-data hasil pengukuran yang dapat diakses melalui alamat web thingspeak.com. Data yang akan disimpan dan dibaca pada cloud diakses menggunakan kode API yang telah diberikan ketika register melalui website thingspeak.com

3. Simulator PLN milik Laboratorium Teknik Tenaga Listrik merupakan simulator sinkronisasi antara grid dengan saluran tiga fasa dari PLN, dimana grid disini merupakan generator yang dikopel dengan motor DC sebagai penggerak utama, dan power supply sebagai sumber tegangan DC, dibantu dengan rheostat yang digunakan untuk mengatur arus yang masuk pada motor DC.

\section{B. Saran}

Setelah diambil beberapa kesimpulan maka dapat diberikan saran sebagai berikut.

1. Wiring antar sensor dengan input maupun output pada sistem elektronis piranti monitoring ini dapat dibuat dengan me-routing sistem dan tidak menggunakan kabel jumper.

2. Penggunaan jaringan $\mathrm{WiFi}$ untuk mengirimkan data pada NodeMCU ini dipastikan dalam koneksi yang baik sehingga pembacaan data pada Thingspeak dapat berlangsung real time.

3. Penggunaan piranti monitoring ini belum melalui pengujian kerja secara terus menerus sehingga perlu dilakukan uji coba dalam waktu yang lama untuk menjamin keandalan system ini.

4. Penggunaan platform Thingspeak dapat diganti dengan XAMPP sebagai data collector dan terhubung dengan aplikasi yang dibuat menggunakan android studio sehingga didapatkan data secara real time dan dapat dikonversi menjadi data dalam bentuk exc.

\section{REFERENSI}

[1] Aminullah, M. (2017). Pengukur Daya Listrik Menggunakan Sensor Arus ACS712- 05A dan Sensor Tegangan ZMPT101B. Universitas Negeri Yogyakarta.

[2] Hasiholan, C., Primananda, R., \& Amron, K. (2018). Implementasi Konsep Internet of Things pada Sistem Monitoring Banjir menggunakan Protokol MQTT. 2(12), 6128-6135.

[3] Hudan, I. S. (2018). Rancang Bangun Sistem Monitoring Daya Listrik pada Kamar Kos Berbasis Internet of Things (IoT) Tri Rijianto Abstrak. $O($ April).

[4] Jaya, A. F., Murti, M. A., \& Mayasari, R. (2018). Monitoring Dan Kendali Perangkat Pada Ruang Kelas Berbasis Internet of Things ( Iot) Monitoring and Control Devices on Classrooms Based Internet of Things. E-Proceeding of Engineering, 5(1), 22-31.

[5] Kurniawan, A., Despa, D., \& Komarudin, M. (n.d.). Monitoring Besaran Listrik dari Jarak Jauh pada Jaringan Listrik 3 Fasa Berbasis Single Board Computer BCM2835.(1).

[6] Lasuda, Suharianti. (2010). Analisis terjadinya kebakaran akibat listrik pada bangunan. Universitas Indonesia.

[7] Mnati, M. J., Van den Bossche, A., \& Chisab, R. F. (2017). A smart voltage and current monitoring system for three phase inverters using an android smartphone application. Sensors (Switzerland), 17(4).

[8] Ree, J. De. (2010). Single-phase vs. Three-phase High Power High Frequency Transformers. Jing Xue, 105.

[9] Rohana. (2008). Analisis Perilaku Pelanggan PLN Dalam Pemakaian Daya Listrik, Thesis, Program Pasca Sarjana Teknik Industri Universitas Sumatera Utara. Medan.

[10] Tatipikalawan, P. S., \& Nur, R. (2015). Evaluasi dan Perencanaan Pengembangan Negeri Ambon. 9(1), 7-12.

[11] Waworundeng, J., \& Lengkong, O. (n.d.). Sistem Monitoring dan Notifikasi Kualitas Udara dalam Ruangan dengan Platform IoT Indoor Air Quality Monitoring and Notification System with IoT Platform.

[12] Wibisana, Boromeus. (2008). Analisis Perbandingan Pembacaan KWh meter Analog dengan KWh meter Digital. Universitas Indonesia.Wireless LAN Medium Access Control (MAC) and Physical Layer (PHY) Specification. 